\title{
Use of flathead mullet (Mugil cephalus) in coastal biomonitor studies: review and recommendations for future studies
}

\author{
Nathan J. Waltham ${ }^{*}$,, Peter R. Teasdale ${ }^{c}$, Rod M. Connolly ${ }^{b}$ \\ ${ }^{a}$ Gold Coast City Council, PO Box 5042, Gold Coast Mail Centre, Queensland, 9729, Australia. \\ ${ }^{\mathrm{b}}$ Australian Rivers Institute - Coasts and Estuaries, and School of Environment, Griffith \\ University, Gold Coast Campus, Queensland, 4222, Australia. \\ ${ }^{\mathrm{c}}$ Environmental Futures Centre and School of Environment, Griffith University, Gold Coast \\ Campus, QLD 4222, Australia.
}

*Present Address. Centre for Tropical Water and Aquatic Ecosystem Research (TropWATER), James Cook University, Queensland, 4811, Australia. Tel.: +61 74781 4191; fax +61 74781

5589. Email: nathan.waltham@jcu.edu.au

\begin{abstract}
There has been a widespread world-wide use of flathead mullet, Mugil cephalus, in fish biomonitor studies within the coastal zone. This review summarises this research field, focusing on heavy metals, and considers the implications of the accumulated data. Differences in sampling methodology, tissues analysed and units of reported data provide challenges in assessing and benchmarking these biomonitor studies. The benthic feeding strategy of $M$. cephalus invariably increases exposure risk relative to middle or upper water column feeders, nevertheless contaminant accumulation via direct and indirect pathways was regulated sufficiently such that toxicants were below food guidelines in most coastal regions (32 of the 49 examined). Human health issues can arise if fish are consumed from heavily industrialised regions. Recommendations are provided for future biomonitoring studies, based on the results for M. cephalus but relevant for fish species more broadly, to provide more comparable data so that managers can benchmark against local conditions.
\end{abstract}




\section{Introduction}

The urban coastal landscape consists of a mixture of heavy industry, residential development, port facilities, sewage treatment facilities, golf courses and urban road networks (Pauly et al., 2002; Waltham and Connolly, 2011). This mosaic of anthropogenic activity contributes widespread and varied contamination, often untreated, into the coastal zone, particularly estuaries (Kennish, 2002; Lee et al., 2006). This cocktail of contaminants can persist within the water column or can be stored in sediments for many decades. Consequentially, toxic contaminants are readily available for uptake and accumulation in coastal food webs rendering estuaries, in particular, of interest for biomonitoring studies. Consumption of contaminated local seafood has implications for human health and is of interest to coastal managers challenged with achieving ecosystem conservation while approving further urban development.

Modern monitoring programs frequently integrate fish data and measurements with abiotic parameters (e.g. measures of water and sediment quality) to allow evaluation of the response and resilience of fish species to contaminants in coastal ecosystems (e.g. Water framework directive of the European Union, Allan et al., 2006; Chesapeake Bay Health and Restoration Assessment, www.chesapeakebay.org, Chesapeake Bay Program, 2008). These biomonitoring programs have been particularly successful because of the advantages over targeted water and sediment programs, including direct insight into ecosystem response to contamination, mechanisms of contaminant uptake by fish, and because their loss has societal costs (Whitfield and Elliott, 2002). The uptake of contaminants by fish is generally known to be either via indirect or direct pathways, with distinction between each route assessed by examining specific tissue types that will accumulate higher contaminant concentrations over other tissue types (Dallinger et al., 1987).

Mugil cephalus, (flathead mullet; other common names include striped mullet and sea mullet) inhabit estuarine intertidal, freshwater and coastal marine habitats worldwide from approximately $42^{\circ} \mathrm{N}$ to $42^{\circ} \mathrm{S}$ latitude (Whitfield et al., 2012). Of all the species within the family Mugilidae, $M$. cephalus is the most abundant and commonly caught in fish investigations. Juvenile fish $(<25 \mathrm{~mm})$ are primarily planktonic or carnivorous feeders, whereas beyond that size diet switches to primarily detritivorous, ingesting large amounts of organic matter, sand or mud from the sediment of waterways (Whitfield et al., 2012). M. cephalus tends to have a longer gut length compared to other fish species, which would conceivably increase absorption efficiency of contaminants once ingested (Odum, 1970). M. cephalus supports commercial and recreational fisheries owing to the high protein and vitamins contained in the muscle tissue, the value of roe from females, and are a stable food source in many countries (Whitfield et al., 2012).

This study presents the first review of biomonitor studies, focusing only on heavy metals, published on Mugil cephalus. We examined which coastal regions contained 
fish unsafe for human consumption, and attempted to evaluate mechanisms of contaminant uptake. We also provide recommendations for future biomonitor studies to facilitate an objective determination of global benchmarking for local fish contamination.

\section{Methods}

\subsection{Search method}

In order to capture publications investigating biomonitoring using Mugil cephalus, the literature was examined using the key words: mugil cephalus* AND heavy metals* AND contaminants* AND coastal zone* AND estuaries*. These search terms were applied to 3 major biological databases: Aquatic Sciences Fisheries Abstracts, Web of Science, and Proquest. In addition, we used Google Scholar search engine to locate government or non-government organisation publications. In all cases, the search approaches were crossed-referenced against one another to produce a final selection of studies ensuring the widest search of the literature. Studies of $M$. cephalus kept in aquaculture facilities, or those specifically examining organophosphates and organochlorines were excluded because of the low number of studies for any meaningful analysis.

\subsection{Meta-analysis}

Water, sediment and fish tissue data presented in each publication fitting the above criteria were extracted and stored in a database. In situations where the laboratory limit of detection was shown, the result was halved (Quinn and Keough, 2008). In all cases, the average concentration value presented in publications was used. Most publications provided data in tabular format, however, in some cases the data was retrieved directly from graphs, with the primary author contacted on several occasions to clarify interpretation. Several publications included reference sites to benchmark conditions against samples collected from polluted sites; both the reference and impact site data were included in the review in these instances.

Examination of Mugil cephalus contaminant concentrations among studies was problematic given the array of different units used, in particular regarding use of either dry weight or wet weight. To standardise this measurement we adjusted for the water content in tissue following Kirby et al., (2001), where a correction factor of 4.5 was applied to wet tissue results to compensate for the dilution of metal concentrations caused by excess water content. This correction factor is in agreement with Marks et al., (1980), who reported a similar relationship for a range of fish species, including $M$. cephalus, regardless of metal element (nine examined). We also standardised differences in the reported unit mass of metals (e.g. $\mathrm{mg} / \mathrm{kg}$ and $\mu \mathrm{g} / \mathrm{g}$ ), such that all values presented are $\mu \mathrm{g} / \mathrm{g}$. Because of the range of guidelines available for comparison to metal concentrations recorded in different studies, we standardised this assessment by using the water (95\% ecosystem protection) and sediment guidelines from the Australian and New Zealand Guidelines for Fresh and Marine Water Quality 
(ANZECC/ARMCANZ, 2000) and the Australian and New Zealand Food Safety Standard (ANZFA, 1999) for edible muscle tissue analysis. We have selected these water guidelines for the basis of this assessment as they are very comprehensive and represent a major development in water quality guidelines. The guideline trigger values for toxicants in water are risk-based and derived from appropriate international toxicity data and some Australian and New Zealand data (Warne, 2001); the toxicity data for relevant organisms was arranged in a statistical distribution and the trigger values for the different levels of protection obtained by extrapolation. The sediment guidelines are based on other international guidelines (ANZECC/ARMCANZ, 2000).

\section{Results and discussion}

\subsection{Summary of meta-analysis}

This is the first study to complete an evaluation of fish biomonitor studies for a single species with study sites spread across many coastal locations around the globe. A total of 49 Mugil cephalus biomonitor studies were included in our evaluation, encompassing a large proportion of the geographical range of this species (Table 1). All studies had a similar research objective, but there were often major differences in the approach used, including sampling methods and data collection. For example, there were differences from study to study in collection of $M$. cephalus, with just over half (55\%) the studies using traditional gill nets and traps, while the remaining $45 \%$ purchased specimens directly from professional fishermen. Direct netting allows better quality control over handling and storage than purchasing, but potentially results in unnecessary bycatch of non-target species. While several studies (15\%) included spatial (impact and control sites) and temporal (seasonal) sampling components in the design, most studies centred on a single survey event or season. Contaminant concentration data were reported using different units (e.g. $\mu \mathrm{g} / \mathrm{g}$ dry weight, $\mu \mathrm{g} / \mathrm{g}$ wet weight, $\mathrm{mg} / \mathrm{kg}$ dry weight, $\mathrm{mg} / \mathrm{kg}$ wet weight). In several cases where no units were reported we clarified units of measurement with the primary author. There were also variations in the fish organs tested, and while most studies included gills, liver and muscle, or a combination of these, several studies included brains, kidney, gonads, roe, blood, heart, intestine, stomach, spline, and bone fragments. There were differences in the list of different contaminants examined; a reaction, presumably, to local environmental conditions, land use practices, management priorities, or known contaminant problems. All these variations have posed a challenge for our comparison, and careful assessment and consideration was given. 
Table 1. Summary of global mullet (Mugil cephalus) biomonitor investigations.

\begin{tabular}{|c|c|c|c|c|c|c|c|c|c|c|}
\hline \multirow[t]{3}{*}{ Author } & \multirow{3}{*}{$\begin{array}{l}\text { Continent/country/ } \\
\text { habitat }(\mathrm{N})\end{array}$} & \multirow{3}{*}{$\begin{array}{l}\text { Sampling design and } \\
\text { Collection methods }\end{array}$} & \multirow{3}{*}{$\begin{array}{l}\text { Length } \\
(\mathrm{mm}, \mathrm{TL})\end{array}$} & \multirow{3}{*}{$\begin{array}{l}\text { Weight } \\
(\mathrm{g})\end{array}$} & \multirow{3}{*}{ 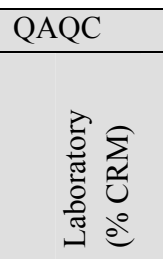 } & \multirow{2}{*}{\multicolumn{2}{|c|}{ Environment }} & \multirow{2}{*}{\multicolumn{3}{|c|}{ Fish Tissue }} \\
\hline & & & & & & & & & & \\
\hline & & & & & & 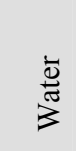 & $\begin{array}{l}\stackrel{\Xi}{0} \\
\stackrel{\Xi}{\Xi} \\
\mathscr{D}\end{array}$ & $\stackrel{n}{\overline{0}}$ & $\stackrel{\vec{\Delta}}{\stackrel{\lrcorner}{a}}$ & $\begin{array}{l}\frac{0}{U} \\
\stackrel{\mathscr{m}}{\Sigma}\end{array}$ \\
\hline 1) Windom et al. (1973) & $\begin{array}{l}\text { Nth America: Gulf Stream, Sargasso Sea (Sth } \\
\text { Carolina, Georgia, Florida) (11) }\end{array}$ & Various locations & $\mathrm{X}$ & $\mathrm{X}$ & $\begin{array}{c}\checkmark \\
10-30\end{array}$ & $\mathrm{X}$ & $\mathrm{X}$ & $\mathrm{X}$ & $\mathrm{X}$ & $\overline{\checkmark \wedge}$ \\
\hline 2) Eustace (1974) & Australia: Derwent Estuary (38) & $\begin{array}{l}\text { Purchased over 8wks between Nov } \\
1972 \text { - Jan } 1973\end{array}$ & $\begin{array}{c}\checkmark * \\
190-27 \\
\text { FL }\end{array}$ & $\mathrm{X}$ & $\mathrm{X}$ & $\mathrm{X}$ & $\mathrm{X}$ & $\mathrm{X}$ & $\mathrm{X}$ & $\checkmark \wedge \wedge$ \\
\hline 3) Bebbington et al. (1977) & Australia: Unknown, NSW (30) & Unknown & $\begin{array}{c}\checkmark * \\
280-540 \\
\text { FL }\end{array}$ & $\begin{array}{c}\checkmark * \\
295-2800\end{array}$ & $\begin{array}{c}\checkmark \\
90-100\end{array}$ & $\mathrm{X}$ & $\mathrm{X}$ & $\mathrm{X}$ & $\mathrm{X}$ & $\checkmark^{\wedge}$ \\
\hline 4) Plaskett and Potter (1979) & Australia: Cockburn Sound (57) & $\begin{array}{l}\text { Seine, trawl or mesh nets, across } \\
\text { known metal pollution gradient }\end{array}$ & $\begin{array}{c}\checkmark * \\
130-330\end{array}$ & $\begin{array}{c}\checkmark * \\
13-301\end{array}$ & $\begin{array}{c}\checkmark \\
95-105\end{array}$ & $\mathrm{X}$ & $\mathrm{X}$ & $\mathrm{X}$ & $\mathrm{X}$ & $\checkmark \wedge \wedge$ \\
\hline 5) Marks et al. (1980) & Australia: Swan-Avon Estuary (163) & $\begin{array}{l}\text { Beach seine \& gill net at } 10 \\
\text { locations covering } 28 \mathrm{~km} \text { between } \\
\text { Feb1987 - Apr } 1979\end{array}$ & $\begin{array}{c}\checkmark * \\
55-430\end{array}$ & $\begin{array}{c}\checkmark * * \\
24-832\end{array}$ & $\begin{array}{c}\checkmark \\
95-105\end{array}$ & $\mathrm{X}$ & $\mathrm{X}$ & $\mathrm{X}$ & $\mathrm{X}$ & $\checkmark \wedge \wedge$ \\
\hline 6) Hamza-Chaffai and Abed (1996) & Tunisia: Middle Eastern Coast (4) & Sep \& Oct 1989 & $\mathrm{X}$ & $\mathrm{X}$ & $\begin{array}{c}\checkmark \\
\text { within 4-9 }\end{array}$ & $\mathrm{X}$ & $\mathrm{X}$ & $\mathrm{X}$ & $\mathrm{X}$ & $\checkmark \wedge \wedge$ \\
\hline 7) Sultana and Rao (1998) & $\begin{array}{l}\text { India: } \\
\text { (a) Visakhapatnam Harbour (46) } \\
\text { (b) Gostani Estuary (10) }\end{array}$ & $\begin{array}{l}\text { Monthly between Mar } 1986 \text { - } \\
\text { Feb1987 from impacted harbour } \\
\text { monthly during summer of } 1986 \text {, } \\
\text { as controls }\end{array}$ & $\mathrm{X}$ & $\mathrm{X}$ & $\mathrm{X}$ & $\checkmark$ & $\mathrm{X}$ & $\checkmark$ & $\checkmark$ & $\checkmark \wedge$ \\
\hline 8) Kalay and Canli (1999) & Turkey: NE Mediterranean Sea (60) & Purchased Nov 1996 & $\begin{array}{c}\checkmark * \\
269 \pm 25.3\end{array}$ & $\begin{array}{c}\checkmark * \\
182 \pm 49\end{array}$ & $\begin{array}{c}\checkmark \\
\text { within } 10\end{array}$ & $\mathrm{X}$ & $\mathrm{X}$ & $\checkmark$ & $\checkmark$ & $\checkmark \wedge \wedge$ \\
\hline 9) Maher et al. (1999) & Australia: Lake Macquarie (36) & Gill net in Apr 1997 & $\mathrm{X}$ & $\begin{array}{l}\checkmark * * \\
\mathrm{NP}\end{array}$ & $\begin{array}{c}\checkmark \\
\text { within } 98\end{array}$ & $\mathrm{X}$ & $\mathrm{X}$ & $\mathrm{X}$ & $\mathrm{X}$ & $\checkmark \wedge \wedge$ \\
\hline 10) Colombo et al. (2000) & Sth America: Rio de la Plata Estuary (30) & Collected between Oct - Dec 1996 & $\checkmark *$ & $\checkmark *$ & $\checkmark$ & $\mathrm{X}$ & $\mathrm{X}$ & $\mathrm{X}$ & $\mathrm{X}$ & $\checkmark \wedge$ \\
\hline
\end{tabular}




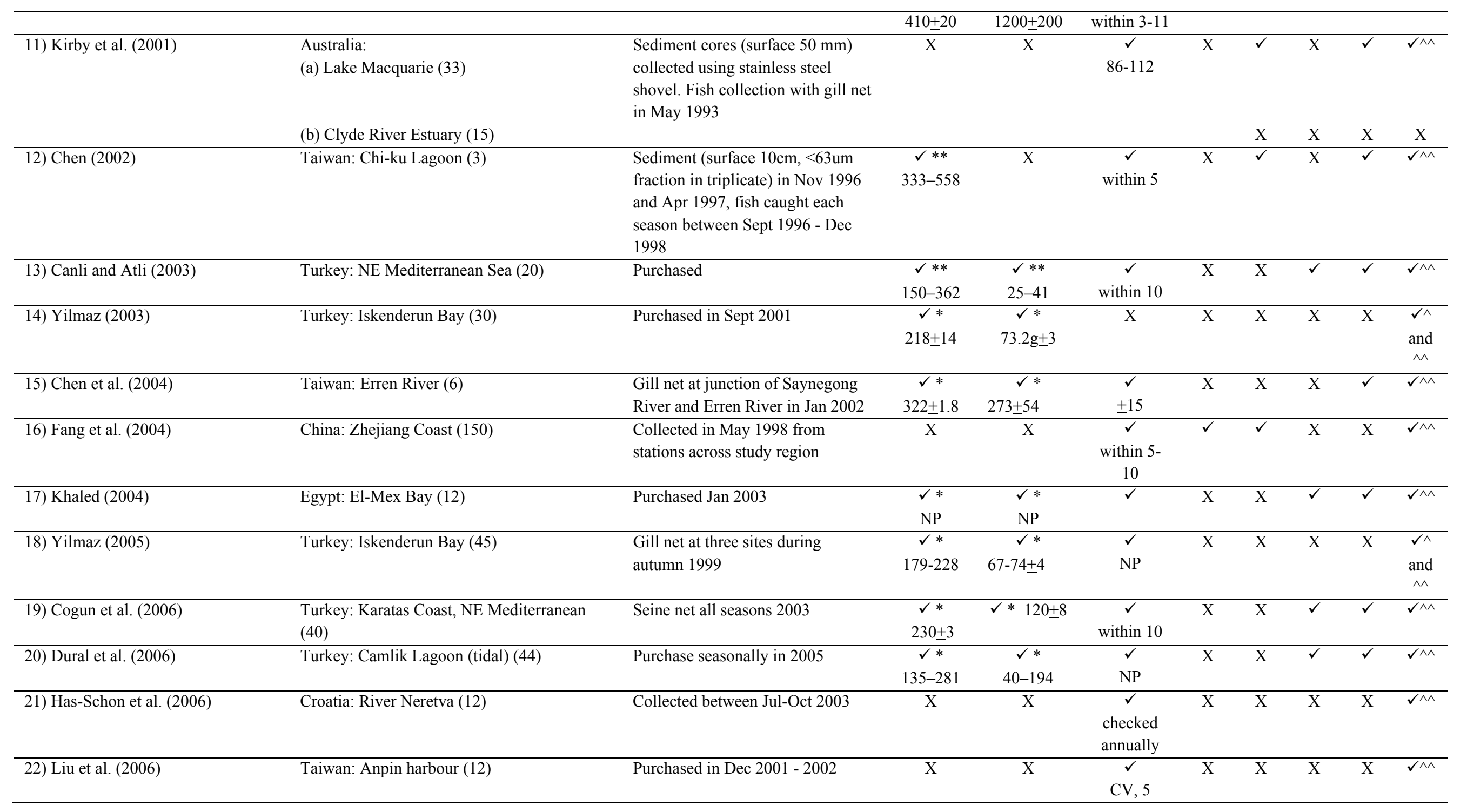




\begin{tabular}{|c|c|c|c|c|c|c|c|c|c|c|}
\hline 23) Turkmen et al. (2006) & Turkey: Iskenderun Bay (45) & Gill net & $\begin{array}{c}\checkmark * \\
\text { Ave } \\
256 \pm 23.5\end{array}$ & $\begin{array}{c}* \\
\text { Ave } \\
175 \pm 36\end{array}$ & $\begin{array}{c}\checkmark \\
93-100\end{array}$ & $\mathrm{X}$ & $\mathrm{X}$ & $\mathrm{X}$ & $\mathrm{X}$ & $\checkmark \wedge \wedge$ \\
\hline 24) Authman and Abbas (2007) & Egypt: Lake Qarun (100) & Purchased Mar 2004 - Feb 2005 & $\begin{array}{c}\checkmark * \\
\text { Ave } 224\end{array}$ & $\begin{array}{c}\checkmark * \\
\text { Ave } 183\end{array}$ & $\mathrm{X}$ & $\checkmark$ & $\mathrm{X}$ & $\checkmark$ & $\checkmark$ & $\sqrt{\checkmark^{\wedge \wedge}}$ \\
\hline 25) Chouba et al. (2007) & Tunisia: Ghar El Melh Lagoon (60) & Purchased seasonally in 2004 & $\begin{array}{c}\checkmark * \\
250-300\end{array}$ & $\begin{array}{c}\checkmark * \\
\text { Ave } \\
14.3+2.2\end{array}$ & $\checkmark$ & $\mathrm{X}$ & $\mathrm{X}$ & $\mathrm{X}$ & $\checkmark$ & $\checkmark \wedge \wedge$ \\
\hline 26) Dural et al. (2007) & Turkey: Tuzla Lagoon (76) & $\begin{array}{l}\text { Purchased seasonally Dec } 2000 \text { - } \\
\text { Nov } 2001\end{array}$ & $\begin{array}{c}* \\
145-271 \\
\end{array}$ & $\begin{array}{c}\checkmark * \\
36-186 \\
\end{array}$ & $\begin{array}{c}\checkmark \\
96-106\end{array}$ & $\mathrm{X}$ & $\mathrm{X}$ & $\checkmark$ & $\checkmark$ & $\checkmark \wedge \wedge$ \\
\hline $\begin{array}{l}\text { 27) Ruelas-Inzunza and Paez-Osuna } \\
\text { (2007) }\end{array}$ & $\begin{array}{l}\text { Sth America: } \\
\text { (a) Guaymas Lagoon, East Gulf of California } \\
\text { (3) } \\
\text { (b) Altata-Ensendada del Pabellion Lagoon } \\
\text { (3) }\end{array}$ & Purchased Apr 1998 - Jan 1999 & $\begin{array}{c}\checkmark * \\
290-410\end{array}$ & $\begin{array}{c}\checkmark * \\
256-580\end{array}$ & $\begin{array}{c} \\
90-115\end{array}$ & $\mathrm{X}$ & $\mathrm{X}$ & $\checkmark$ & $\checkmark$ & $\checkmark \wedge \wedge$ \\
\hline 28) Uluozlu et al. (2007) & Turkey: Black Sea (6)++ & Purchased in 2005 & $\mathrm{X}$ & $\mathrm{X}$ & $\begin{array}{c}\checkmark \\
95-101 \\
\end{array}$ & $\mathrm{X}$ & $\mathrm{X}$ & $\mathrm{X}$ & $\mathrm{X}$ & $\sqrt{ } \wedge \wedge$ \\
\hline 29) Huang et al. (2008) & Taiwan: Reservoir near Tainan City (5) & $\begin{array}{l}\text { Collected between Sept and Oct } \\
2003\end{array}$ & $\begin{array}{c}\checkmark * \\
235-40 \\
\text { FL }\end{array}$ & $\begin{array}{c}\checkmark * \\
176-930\end{array}$ & $\begin{array}{c}\checkmark \\
\text { within } 5\end{array}$ & $\mathrm{X}$ & $\mathrm{X}$ & $\mathrm{X}$ & $X$ & $\checkmark \wedge \wedge$ \\
\hline 30) Prasath and Khan (2008) & $\begin{array}{l}\text { India: Poompuhar Coast (NP) } \\
\text { (a) Pre tsunami } \\
\text { (b) Post tsunami }\end{array}$ & $\begin{array}{l}\text { Water, sediment and fish collected } \\
\text { in Nov } 2004 \text { and Jan } 2005 \text { (pre and } \\
\text { post tsunami) }\end{array}$ & $\begin{array}{c}\checkmark * \\
90-270\end{array}$ & $\mathrm{X}$ & $\mathrm{X}$ & $\checkmark$ & $\checkmark$ & $\mathrm{X}$ & $\mathrm{X}$ & $\sqrt{\checkmark^{\wedge}}$ \\
\hline 31) Uysal et al. (2008) & Turkey: Beymelek Lagoon (3) & Collected Nov 2006 & $\begin{array}{c}\checkmark * \\
\text { Ave } \\
299 \pm 10.9\end{array}$ & $\begin{array}{c}\checkmark * \\
\text { Ave } \\
261 \pm 30\end{array}$ & $\begin{array}{c}\checkmark \\
\text { NP }\end{array}$ & $\mathrm{X}$ & $\mathrm{X}$ & $\checkmark$ & $\mathrm{X}$ & $\sqrt{\checkmark^{\wedge \wedge}}$ \\
\hline 32) Bahnasawy et al. (2009) & Egypt: Lake Manzala (NP) & Collected from study sites & $\mathrm{X}$ & $\mathrm{X}$ & $\mathrm{X}$ & $\mathrm{X}$ & $\mathrm{X}$ & $\checkmark$ & $\mathrm{X}$ & $\begin{array}{c}\checkmark \wedge \\
\text { and } \\
\wedge \wedge\end{array}$ \\
\hline 33) Boubonari et al. (2009) & Turkey: Monolimni Lagoon (12) & $\begin{array}{l}\text { Nets seasonally May } 1998 \text { - May } \\
1999\end{array}$ & $\mathrm{X}$ & $\mathrm{X}$ & $\begin{array}{c}\mathrm{X} \\
\mathrm{CV}, 1-19\end{array}$ & $\checkmark$ & $\checkmark$ & $\mathrm{X}$ & $\mathrm{X}$ & $\sqrt{\checkmark^{\wedge}}$ \\
\hline 34) Padmini et al. (2009) & India: Ennore Estuary (216)++ & $\begin{array}{l}\text { Traps, monthly between Oct } 2004 \\
\text { to Sept } 2006\end{array}$ & $\begin{array}{c}\checkmark * \\
320-350\end{array}$ & $\mathrm{X}$ & $\mathrm{X}$ & $\mathrm{X}$ & $\mathrm{X}$ & $\mathrm{X}$ & $\checkmark$ & $\checkmark \wedge \wedge$ \\
\hline
\end{tabular}




\begin{tabular}{|c|c|c|c|c|c|c|c|c|c|c|}
\hline \multirow[t]{3}{*}{ 35) Tapia et al. (2009) } & Sth America: & Purchased winter 2005 and spring & $\mathrm{X}$ & $\mathrm{X}$ & $\checkmark$ & $\mathrm{X}$ & $X$ & $X$ & $\mathrm{X}$ & $\checkmark \wedge \wedge$ \\
\hline & (a) Maula River (46) & 2005, autumn 2006 and summer & & & $92-109$ & & & & & \\
\hline & (b) Mataquito River (46) & 2006 & & & & $\mathrm{X}$ & $\mathrm{X}$ & $\mathrm{X}$ & $\mathrm{X}$ & $\checkmark \wedge \wedge$ \\
\hline \multirow[t]{2}{*}{ 36) Tuzen (2009) } & Turkey: Black Sea (4) & Purchased during 2008 & $X$ & $\mathrm{X}$ & $\checkmark$ & $\mathrm{X}$ & $\mathrm{X}$ & $\mathrm{X}$ & $\mathrm{X}$ & $\checkmark \wedge \wedge$ \\
\hline & & & & & NP & & & & & \\
\hline \multirow[t]{3}{*}{ 37) Yilmaz (2009) } & Turkey: Koycegiz Lake-Mugla (44) & Collected June 2005 - May 2006 & $\checkmark *$ & $\checkmark$ & $\checkmark$ & $\mathrm{X}$ & $\mathrm{X}$ & $\checkmark$ & $\checkmark$ & $\checkmark \wedge \wedge$ \\
\hline & & & Ave & Ave & $92-107$ & & & & & \\
\hline & & & $243 \pm 27.8$ & $85.3 \pm 12$ & & & & & & \\
\hline \multirow[t]{2}{*}{ 38) Frias-Espericueta et al. (2010) } & & Purchased between Aug 2004 and & $\checkmark$ & $\mathrm{X}$ & $\checkmark$ & $\mathrm{X}$ & $\mathrm{X}$ & $\checkmark$ & $\checkmark$ & $\checkmark \wedge \wedge$ \\
\hline & & June 2005 & NP & & $91-106$ & & & & & \\
\hline \multirow[t]{3}{*}{ 39) Ruelas-Izuna et al. (2010) } & Sth America: Gulf of California, Mexico (4) & Purchased from June 2003 and Mar & $\checkmark *$ & $\checkmark$ & $\checkmark$ & $\mathrm{X}$ & $\mathrm{X}$ & $\checkmark$ & $\checkmark$ & $\checkmark \wedge \wedge$ \\
\hline & & 2004 & Ave 269 & Ave & NP & & & & & \\
\hline & & & NP & $193+52$ & & & & & & \\
\hline \multirow[t]{2}{*}{ 40) Frias-Espericueta et al. (2011) } & Sth America: Coastal lagoons, Mexico (15) & Purchased - Mar 2006 - Jan 2007 & $\mathrm{X}$ & $\mathrm{X}$ & $\checkmark$ & $\mathrm{X}$ & $\mathrm{X}$ & $\checkmark$ & $\checkmark$ & $\checkmark \wedge \wedge$ \\
\hline & & & & & $91-106$ & & & & & \\
\hline \multirow[t]{2}{*}{ 41) Karouna-Renier et al. (2011) } & Nth America: estuaries in Florida & Collected spring 2004 and 2005 & $\checkmark$ & $\mathrm{X}$ & $\checkmark$ & $\mathrm{X}$ & $\mathrm{X}$ & $\mathrm{X}$ & $\mathrm{X}$ & $\checkmark \wedge$ \\
\hline & & using electrofishing and cast nets & NP & & $75-120$ & & & & & \\
\hline 42) Ambedkar and Muniyan (2011) & India: Vella River, Tamil Nadu (na) & Purchased from Jan to June 2010 & $\mathrm{X}$ & $\mathrm{X}$ & $\mathrm{X}$ & $\mathrm{X}$ & $\mathrm{X}$ & $\mathrm{X}$ & $\mathrm{X}$ & $\checkmark \wedge \wedge$ \\
\hline \multirow[t]{3}{*}{ 43) Priya et al. (2011) } & India: (12) & Purchased May 2009 & $\mathrm{X}$ & $\mathrm{X}$ & $\checkmark$ & $\checkmark$ & $\checkmark$ & $\checkmark$ & $\checkmark$ & $\checkmark \wedge \wedge$ \\
\hline & (a) Pulicat Lake & & & & $95-100$ & & & & & \\
\hline & (b) Barmouth (opening to sea) & & & & & $\checkmark$ & $\checkmark$ & $\checkmark$ & $\checkmark$ & $\checkmark \wedge \wedge$ \\
\hline \multirow[t]{2}{*}{ 44) Sacan and Altun (2011) } & Turkey: Kuckukekmece Lagoon (24) & Purchased seasonally, winter 2002 & $\checkmark * *$ & $\checkmark * *$ & $\checkmark$ & $\mathrm{X}$ & $\mathrm{X}$ & $\mathrm{X}$ & $\mathrm{X}$ & $\checkmark \wedge \wedge$ \\
\hline & & to autumn 2003 & $170-340$ & $263-543$ & $82-94$ & & & & & \\
\hline \multirow[t]{6}{*}{ 45) Waltham et al. (2011) } & Australia: Moreton Bay: & Collected from each habitat in & $\checkmark * *$ & $\mathrm{X}$ & $\checkmark$ & $\checkmark$ & $\checkmark$ & $\checkmark$ & $\checkmark$ & $\checkmark \wedge$ \\
\hline & (a) Marina (20) & Winter 2006 & $170-340$ & & DGT 90; & & & & & \\
\hline & (b) Estuaries (20) & & & & sediment & & & & & \\
\hline & (c) Natural (20) & & & & 40-100; & & & & & \\
\hline & (d) Canals (20) & & & & muscle $85-$ & & & & & \\
\hline & (e) Lakes (20) & & & & 115 & & & & & \\
\hline \multirow[t]{2}{*}{ 46) Djedjibegovic et al. (2012) } & Bosnia/Herzegovina: Neretva River (7) & Collected by angling Oct-Nov & $\checkmark *$ & $\checkmark *$ & $\checkmark$ & $\mathrm{X}$ & $\mathrm{X}$ & $\mathrm{X}$ & $\checkmark$ & $\checkmark \wedge \wedge$ \\
\hline & & 2003 & Ave 289 & Ave 192 & $90-96$ & & & & & \\
\hline \multirow[t]{3}{*}{ 47) Khoshnood et al. (2012) } & Iran: Normoz Strait, Oman Sea and Persian & Purchased monthly from Apr 2009- & $\checkmark *$ & $\checkmark *$ & $\checkmark$ & $\mathrm{X}$ & $\mathrm{X}$ & $\checkmark$ & $\checkmark$ & $\checkmark \wedge \wedge$ \\
\hline & Gulf $(24)$ & Mar 2010 & Ave & Ave & $95-130$ & & & & & \\
\hline & & & $173 \pm 22$ & $480 \pm 300$ & & & & & & \\
\hline
\end{tabular}




\begin{tabular}{|c|c|c|c|c|c|c|c|c|c|c|}
\hline 48) Medeiros et al. (2012) & $\begin{array}{l}\text { Sth America: Coast of Rio de Janeiro State } \\
\text { (5) }\end{array}$ & Purchased Apr-July 2009 & $\mathrm{X}$ & $\mathrm{X}$ & $\begin{array}{c}\checkmark \\
70-120\end{array}$ & $\mathrm{X}$ & $\mathrm{X}$ & $\mathrm{X}$ & $\mathrm{X}$ & $\checkmark \wedge \wedge$ \\
\hline 49) Mohan et al. (2012) & India: Cochin, Vembanad Lake (na) & $\begin{array}{l}\text { Purchased during pre-monsoon } \\
\text { season }\end{array}$ & $\begin{array}{c}\checkmark * \\
\text { Ave } \\
234 \pm 20\end{array}$ & $\begin{array}{c}\checkmark * \\
\text { Ave } \\
68-131 \\
\pm 2-13\end{array}$ & $\begin{array}{c}\checkmark \\
96-103\end{array}$ & $\mathrm{X}$ & $\mathrm{X}$ & $\checkmark$ & $\checkmark$ & $\checkmark \wedge \wedge$ \\
\hline Percentage of investigation & etails & & 65 & 51 & 65 & 18 & 14 & 44 & 47 & 100 \\
\hline
\end{tabular}

$\mathrm{N}$, number of fish examined shown in habitat column

$\mathrm{X}$, no data

$\mathrm{NP}$, not presented

* relationship between fish tissue metal concentrations and length or weight not examined, ** length and weight relationship with fish tissue metal concentrations examined

$\wedge$ skin removed, ${ }^{\wedge}$ skin (presumably) not removed before muscle before analysis

++ approximate calculation of fish number

TL, total length of fish

FL, folk length of fish

$\mathrm{CV}$, coefficient of variance (ratio of standard deviation to the mean in a string of results) 
Cite As: Waltham NJ, Teasdale PR, Connolly RM (2013) Use of flathead mullet (Mugil cephalus) in coastal biomonitor studies: review and recommendations for future studies. Marine Pollution Bulletin 69:195-205

Biomonitor surveys have an inherent surveillance monitoring focus whereby attention is centred on examining the impact that local land use activities have on water, sediment and fish contaminant levels. All studies had this focus, but also had a secondary objective of determining whether metal concentrations in edible muscle tissue pose a human health risk. Only a small subset of the total studies had a research focus, for example, Maher et al. (1999) examined the distribution of As compounds in a series of fish tissues and was able to construct a conceptual model of total As and As compounds in tissue relative to the circulatory system. Two studies had a strong statistical experimental design; one used a BACI design (Before After Control Impact) to examine the success of land use restoration on decreasing heavy metal concentrations in the tissue of M. cephalus (Huang et al. 2008). The second study inspected changes in fish tissue heavy metals collected before and after a tsunami (Prasath and Khan, 2008).

\subsection{Consideration of fish biology in biomonitor studies}

\subsubsection{Fish size, weight and sex}

Understanding the biology of the target fish species is important in biomonitoring surveys particularly given a tendency of ontogenetic shift in diet, habitat preference changes, spawning patterns and condition tolerances, all of which conceivably confound results. Many studies included fish size and weight measurement (e.g. range or average measurement), but these data were often underutilised and in many cases were presented simply as a range, with no further examination for correlation with metal concentrations. Such morphological measurements have been used successfully to calculate a fish condition factor as a surrogate for fish health. This calculation is based on a length-weight relationship with higher condition factor evidence that fish are healthier compared to fish with a low factor. In a novel application of this calculation, Bervoets and Blust (2003) developed threshold metal concentration values for a gudgeon species above which resulted in a low condition factor, therefore reflecting low fish health, while below the threshold fish were considered healthy. Development of similar metal thresholds for $M$. cephalus would help managers evaluate exposure risks to fish, and indirectly to humans, in response to a proposed urban development and land use change which contributes to increased contaminant runoff.

Biomagnification and bioaccumulation of contaminants in fish continues to be of interest to scientists and managers (Bervoets et al., 2005), and follows the trend of accumulation of contaminants in fish as they become larger /older. In the few studies that examined effect of fish length and weight on fish metal concentrations, no relationships were found and therefore no adjustment for size or weight was made. While this may be the case in the studies examined in this review, examination of fish size and weight should remain in future biomonitor studies in order to decipher implications on tissue metal concentrations more broadly in coastal regions.

The reproductive stage of fish can influence metal concentrations, but is rarely included in biomonitor studies (Yilmaz, 2003). In situations where fish are well advanced 
through the reproductive cycle, it is expected that metals accumulate in the sexual organs of fish (i.e. gonads and ovaries); a response to higher metabolic activities than during other times of the cycle (Karadede and Unlu, 2000). Accumulation of metals during critical phases of fish embryotic development will not only cause concentrations in the organs of fish to increase, but some metal species are known to have deleterious implications on embryotic development (Jones and Reynolds, 1997). In the few studies to consider reproductive organs, the gonads had higher concentrations than gills and muscle, though not than skin tissue (Yilmaz, 2003).

\subsubsection{Implications of including skin in edible tissue analysis}

The skin of fish contains lipids that provide an important defence against bacteria, parasites and infection, but the skin can also effectively store contaminants and is often consumed by humans (Lewis, 1970; Yilmaz, 2003). Several studies (10\%) specifically examined the skinless edible muscle tissue of fish, while for the remaining studies it was not clearly presented whether edible fillets were analysed with or without the attached skin. Four studies examined metal concentrations in both the skin and skinless edible muscle tissue, and found that the skin contained between 20 and $100 \%$ higher metal concentrations than in corresponding skinless edible muscle tissue (Fig. 1). This pattern of higher contaminants in fish skin compared to skinless muscle tissue supports finding in other coastal fish species (e.g. Al-Yousuf et al., 2000; Afonso et al., 2007; Yilmaz and Dogan, 2008). Mindful that fish biomonitor studies typically focus on evaluating safe levels of consumption by humans, examining edible muscle tissue with skin represents the most accurate assessment of human exposure and risk: the skin is more contaminated compared to tissue but small in volume. We are not recommending the analysis of skin-attached over skinless muscle tissue, but recommend that research state whether edible muscle tissue results included skin.

\subsection{Statistical design and quality control}

Many studies (65\%) included a step to establish analytical precision and repeatability in the laboratory analysis, with the precision achieved seemingly adequate. However, a fundamental drawback in all studies was in the level of attention given to field quality control measures. These were often inadequate for water and sediment sampling, compared with measurement of fish tissue where sub-sample of fish tissues were analysed as part of quality control. Water and sediment contaminant concentrations are known to change over many spatial and temporal dimensions (sensu Simpson and Batley, 2007; Mohammed et al., 2012). Without understanding the scale and extent of site heterogeneity, it is difficult and misleading to attempt correlations between water and sediment contaminants measured in fish tissue without additional spatiotemporal data. Any correlation is confounded because of over- or under-estimation in environmental data. The only study to attempt to understand field heterogeneity was Waltham et al. (2011). The authors in that study included a composite sediment sampling technique (3 replicate grabs which were homogenised with a subsample taken for analysis) at each site and the use of time-integrated passive samplers (DGT diffusive gradient in thin film) to evaluate environmental variability. Such a rigorous 
sampling program requires additional funding for analysis and sample collection, however, the financial imposition is overshadowed by the gains afforded with understanding laboratory and sample variance. An auxiliary approach may include examination of historical datasets, which equally achieve greater insight into spatial and temporal contaminant concentrations, but at a reduced cost.

\subsection{Mugil cephalus contaminant concentrations - global comparison}

\subsubsection{Environmental variables}

Very few studies inspected metal concentrations in the water and sediment at the same locations where fish were collected (Table 2). Of the 49 studies, $18 \%$ and $14 \%$ examined either water or sediment contaminants at sites respectively, while only $10 \%$ of studies examined both water and sediment. This low number of studies is probably a consequence of the purchase of fish from commercial fisherman. A secondary reason is probably a reflection of a greater focus on examining human health exposure risks, rather than understanding the mechanisms of contaminant uptake.

Some water and sediment anomalies are presented, in particular, $\mathrm{Cu}, \mathrm{Pb}$ and $\mathrm{Zn}$ which exceed the ANZECC/ARMCANZ (2000) 95\% level of aquatic ecosystem protection guidelines (Table 2). Sources of $\mathrm{Cu}, \mathrm{Pb}$ and $\mathrm{Zn}$ in coastal waters are many and varied, such as vehicle road runoff, discharge from smelting and industrial facilities, sewage treatment plants and antifouling paints on vessels, and determining a single source among many would be difficult (Lee et al., 2006; Waltham et al., 2011), unless a comprehensive monitoring program was undertaken (Dunn et al., 2007; Chen et al., 2012; Reese et al., 2012).

Sultana and Rao (1998) recorded the highest water metal concentrations in the impact location. For sediments, the only exceedance was $\mathrm{Pb}$ recorded in Monolimni Lagoon, Turkey, by Boubonari et al., (2009). Curiously, only a single study focused on the $<63$ $\mu \mathrm{m}$ fine sediment fraction, with the remaining studies not offering the size faction examined. The $<63 \mu \mathrm{m}$ sediment fraction is known to yield higher contaminants, because of the greater total surface area of smaller sediment particles, compared to much larger sediment size fractions which have a smaller relative surface area, and is therefore representative of the labile potential within sediments (ANZECC/ARMCANZ, 2000). 
Table 2. Mean water and sediment contaminant concentrations measured in each study. Concentrations in bold exceed the recommended (usually 95\%) trigger value for marine waters and sediment low trigger values (ANZECC/ARMCANZ, 2000). (a) is the impact site, (b) is the reference site for a study. (ND) not detected. In study 45: a) marina; b) estuary; c) open bay natural wetland; d) artificial residential canal; and e) artificial residential lake.

\begin{tabular}{|c|c|c|c|c|c|c|}
\hline Study & As & $\mathrm{Cd}$ & $\mathrm{Cu}$ & $\mathrm{Hg}$ & $\mathrm{Pb}$ & $\mathrm{Zn}$ \\
\hline \multicolumn{7}{|l|}{ Water $(\mu \mathrm{g} / \mathrm{L})$} \\
\hline $7 \mathrm{a}$ & - & - & 17.5 & - & - & 1300 \\
\hline $7 \mathrm{~b}$ & - & - & ND & - & - & 17.6 \\
\hline 16 & 6.8 & 0.05 & 1.5 & 0.02 & 0.7 & 16.8 \\
\hline 24 & - & - & 2.1 & - & - & 0.1 \\
\hline 33 & - & 0.1 & 10 & - & 25.1 & 48.8 \\
\hline $43 a$ & - & 0.36 & 9.2 & - & 5.8 & 32.5 \\
\hline $43 b$ & - & 0.18 & 5.4 & - & 2.2 & 25.1 \\
\hline $45 \mathrm{a}$ & - & 0.02 & 2.3 & - & 0.02 & 23.7 \\
\hline $45 \mathrm{~b}$ & - & 0.01 & 1.4 & - & 0.02 & 20.1 \\
\hline $45 \mathrm{c}$ & - & 0.01 & 1.4 & - & 0.02 & 10.9 \\
\hline $45 \mathrm{~d}$ & - & 0.02 & 0.8 & - & 0.02 & 27 \\
\hline $45 \mathrm{e}$ & - & 0.02 & 0.9 & - & 0.04 & 22.3 \\
\hline Trigger value & - & 0.2 & 1.3 & 0.1 & 4.4 & 15 \\
\hline \multicolumn{7}{|c|}{ Sediment ( $\mu \mathrm{g} / \mathrm{g}$ dry weight) } \\
\hline 11 & - & - & 26.7 & - & - & 126.7 \\
\hline $12^{*}$ & 13 & - & 14.8 & - & 20 & 103 \\
\hline 16 & 8.6 & - & 29.4 & 0.06 & 23.9 & 80.6 \\
\hline $30 \mathrm{a}$ & - & - & 31.4 & - & - & 5.9 \\
\hline $30 \mathrm{~b}$ & - & - & 47.9 & - & - & 7.3 \\
\hline 33 & - & 0.2 & 60 & - & 90 & 70 \\
\hline $43 a$ & - & 1.2 & 31.7 & - & 10.3 & 76.1 \\
\hline $43 b$ & - & 0.9 & 26.4 & - & 8.3 & 63.4 \\
\hline $45 \mathrm{a}$ & 2.1 & 0.1 & 31.5 & - & 14.9 & 71.5 \\
\hline $45 \mathrm{~b}$ & 1.9 & 0.1 & 7.1 & - & 8.6 & 47.5 \\
\hline $45 \mathrm{c}$ & 2.4 & 0.1 & 5.8 & - & 5 & 32.2 \\
\hline $45 \mathrm{~d}$ & 3.5 & 0.1 & 12.2 & - & 48.4 & 105.1 \\
\hline $45 \mathrm{e}$ & 2.6 & 0.1 & 10.6 & - & 39.8 & 76.9 \\
\hline Trigger value & 20 & 1.5 & 65 & - & 50 & 200 \\
\hline
\end{tabular}

(*) results extracted from a graph, compared to all other studies which presented data in tables.

(-) no analysis. 


\subsubsection{Mechanisms of contaminant uptake}

In studies that examine the pathway of uptake of contaminants, accumulation of contaminants in the gills of fish is believed to be associated with available concentrations in the water column. Conversely, uptake of contaminants in food or ingested material, including sediment in the case of Mugil cephalus, is reflected by high metal concentrations in the liver (Heath, 1995). This distribution of metals is a response to primary source of contaminants; water or food. This pattern of contaminant distribution in fish has been widely demonstrated (e.g. Al-Yousuf et al., 2000; Alquezar et al., 2006; Ambedkar and Muniyan, 2011), but most elegantly in manipulated experiments where fish were exposed to a combination of contaminated water and clean food (i.e. gills $>$ liver), and clean water and spiked food (i.e. gills < liver; Kraal et al., 1995). The use of in situ passive samplers (DGT) for a field calibration of oyster biomonitors has also been described (Jordan et al., 2008), and this approach may be useful with fish biomonitors too.

We pooled the data in all studies to examine the metal content in gill, liver and muscle tissue (standardised to $\mu \mathrm{g} / \mathrm{g}$ dry weight) for those routinely investigated metal elements (Fig. 2). The results show an interesting distribution, where As, $\mathrm{Hg}$ and $\mathrm{Zn}$ had no measurable difference in concentrations among the tissues (one-way ANOVA, $\mathrm{df}_{2,125}$ $\mathrm{F}=0.5-18.1, P=0.1-0.59$ ), while $\mathrm{Co}, \mathrm{Cr}$ and $\mathrm{Pb}$ had significantly higher concentrations in gills and liver, compared to muscle tissue $\left(\mathrm{df}_{2,125} \mathrm{~F}=9.5-28.1\right.$, $P<0.01$ ). In contrast, $\mathrm{Cu}$ had a different metal distribution to the other elements, with significantly higher concentrations in liver compared to gills and muscle tissue $\left(\mathrm{df}_{2}, 125\right.$ $\mathrm{F}=44.6, P<0.01)$. Accumulation of metals in the gills and liver tissue at concentrations higher than muscle tissue seems typical for fish within this family. Several studies examined the pathway uptake of contaminants in M. cephalus in comparison to carnivorous and herbivorous fish species, that typically occupy the middle to upper water column, and concluded that the significantly higher concentrations in $M$. cephalus reflects the benthic feeding strategy; it is continually sifting through benthic sediments for food which not only increases exposure to contaminated sediments, but also liberates metals from sediments into the water column after disturbance (Yilmaz, 2005; Dural et al., 2006; Waltham et al., 2011). For this species, there is strong evidence that it can regulate and reduce metals after uptake, and this is demonstrated with higher concentrations in liver over gills for some elements, and vice versa for other metals. The tendency for $M$. cephalus to accumulate highest contaminants in the gills and liver, however, does not conclusively demonstrate whether direct or indirect uptake pathways are operating. These accumulation mechanisms underpinning uptake of contaminants could be investigated with the use of chemical tracers (Xu \& Wang, 2002). 

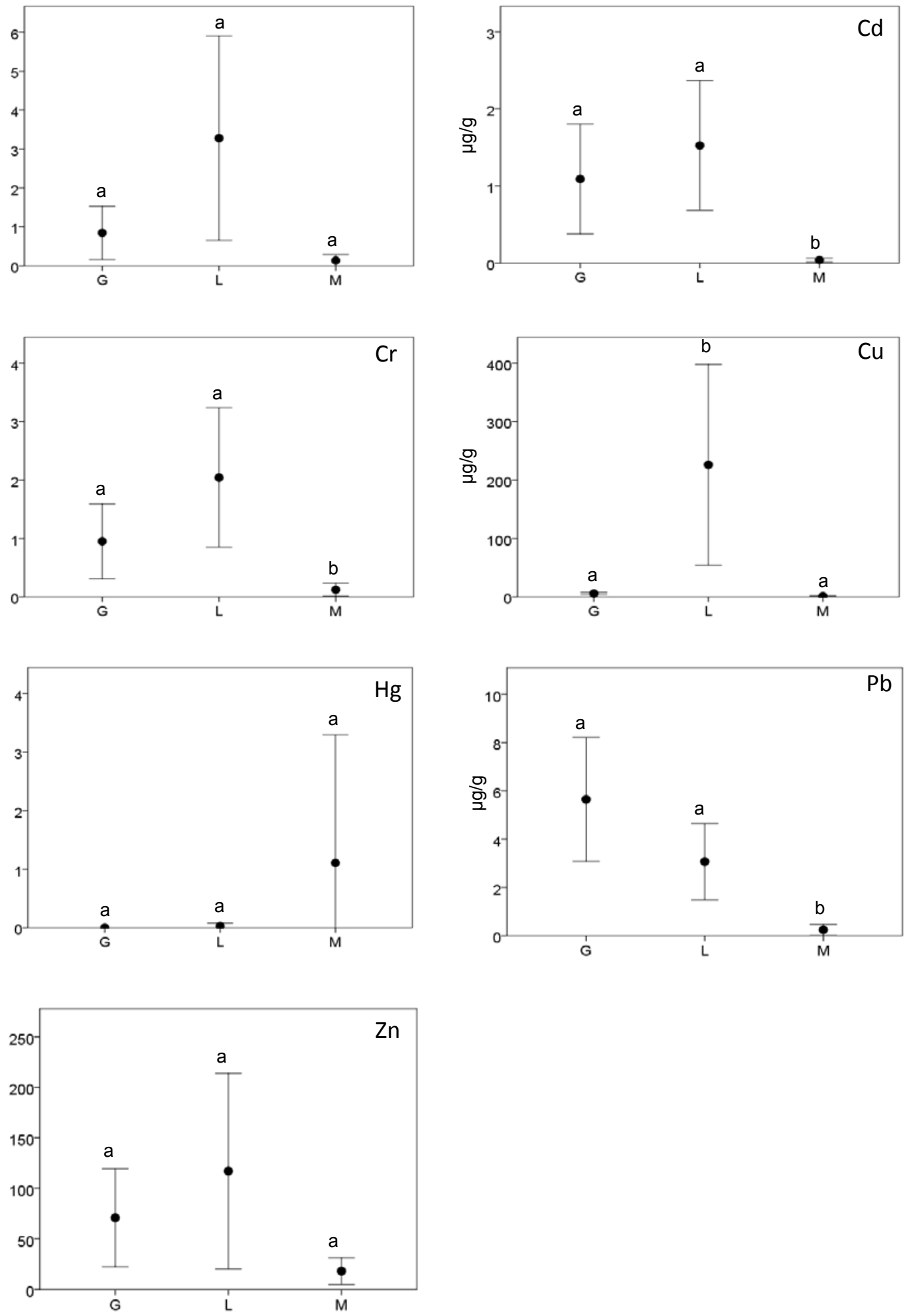

Fig. 2. Mean $(\mu \mathrm{g} / \mathrm{g})$ and standard error $( \pm)$ for measured metal concentrations in $(\mathrm{G})$ gills ( $\mathrm{N}=27)$, (L) liver (36); and (M) muscle tissue (61) for all studies pooled. Values for each tissue with different lower case letters differ significantly between according to Tukey's post hoc test $(\mathrm{p}<0.01)$. 


\subsubsection{Human health risks}

Mugil cephalus was reported to be safe for human consumption in $65 \%$ or 32 coastal regions studied, with no elevated metal concentrations above the presented safe seafood standard (Table 3). However, this also means that the remaining coastal regions had at least one metal element that exceeded guidelines, and therefore the fish were potentially unsafe for human consumption. Of all the elements, $\mathrm{Cd}$ concentrations always complied with the food guidelines and posed no risk to human health. For $\mathrm{Hg}$ and $\mathrm{Zn}$, most studies presented concentrations that complied with food guidelines, with elevated concentrations found in a few studies, from different regions. In the case of $\mathrm{Cu}$, tissue concentrations exceeded the guidelines in several locations, highlighting potential health concerns and also the need to further investigate sources of $\mathrm{Cu}$ in those waterways. Arsenic concentrations were detected above maximum permitted concentrations for human health at several localities, however, the maximum permissible concentration in this standard is based on inorganic As, which typically represents only a small proportion of the total As measured in marine fauna (Edmonds and Francesconi, 1993). It is likely that the method of analysis in each study did not discriminate between inorganic and organic forms of As, therefore we cannot confirm whether these exceeded concentrations in fact satisfy the standard. Lead was the element that most commonly exceeded the guideline, with tissue concentrations 50 times above the safe limit observed. Sources of $\mathrm{Pb}$ in the coastal zone are widespread, including historic or current use of leaded fuel, waste refuge areas, or even lead from recreational fishing sinkers; $\mathrm{Pb}$ is a very ubiquitous contaminant that is known to associate strongly with particulate matter (Luoma and Rainbow, 2008 and the references therein). The dominant route of uptake is therefore likely to be through consumption of particles or sediment, rather than through uptake from water. Trophic transfer of $\mathrm{Pb}$ is considered to be low except in highly contaminated sites (Luoma and Rainbow, 2008 and the references therein).

Overall, Mugil cephalus collected in Turkey (see Boubonari et al., 2009; Yilmaz, 2009) contained the highest muscle concentrations of $\mathrm{Cu}, \mathrm{Pb}$ and $\mathrm{Zn}$, which also exceeded the food guidelines. Tuzen (2009) also completed a study in Turkey and recorded the highest $\mathrm{Hg}$ concentrations of any study using M. cephalus, demonstrating the likelihood of human health risks if consumed: note that Boubonari et al. (2009) and Yilmaz (2009) did not include $\mathrm{Hg}$ in the suite of testing, so it is unknown whether $\mathrm{Hg}$ is an environmental problem more broadly, supporting the underlying theme of this review that inconsistencies exist among studies, especially at a local scale. For managers in Turkey, there is an apparent need to firstly identify bulk sources of contaminants, and to then implement an appropriate program of source control and on-going maintenance. 
Table 3. Mean contaminant concentrations in edible muscle tissue for Mugil cephalus. Reported for those elements where a guideline is available (ANZFA, 1999). (a) is the impact site, while (b) is the reference site. For study 45 same as Table 2.

\begin{tabular}{|c|c|c|c|c|c|c|}
\hline Study & As & $\mathrm{Cd}$ & $\mathrm{Cu}$ & $\mathrm{Hg}$ & $\mathrm{Pb}$ & $\mathrm{Zn}$ \\
\hline 1 & 0.5 & 0.5 & 1.9 & 0.1 & - & 17 \\
\hline 2 & - & 0.1 & 3.2 & - & - & 53.2 \\
\hline 3 & 0.8 & 0.04 & 0.59 & 0.33 & 0.65 & 5.3 \\
\hline 4 & - & 0.22 & 1.71 & - & 1.92 & 22.3 \\
\hline 5 & - & 0.24 & 1.46 & 1.91 & - & 17.4 \\
\hline 6 & - & 0.28 & 19.12 & - & - & 180 \\
\hline $7 a$ & - & 0.36 & 1.82 & - & 3.24 & 23.19 \\
\hline $7 b$ & - & 0.16 & 0.5 & - & 1.22 & 6.56 \\
\hline 8 & - & 0.96 & 4.48 & - & 6.25 & 26.1 \\
\hline 9 & 4.7 & - & - & - & - & - \\
\hline 10 & - & - & 8.5 & - & - & 78.9 \\
\hline $11 \mathrm{a}$ & - & 0.05 & 20 & - & - & 30 \\
\hline $11 \mathrm{~b}$ & - & 0.01 & 5 & - & - & 10 \\
\hline 12 & 0.011 & - & 0.001 & 0.00005 & - & 0.01 \\
\hline 13 & - & 0.66 & 4.41 & - & 5.32 & 37.39 \\
\hline 14 & - & - & 0.006 & - & 0.03 & 0.16 \\
\hline 15 & 0.002 & 0.001 & 0.002 & 0.001 & - & 0.002 \\
\hline 16 & 2.8 & 0.26 & 3.12 & 0.07 & 0.4 & 35.8 \\
\hline 17 & - & 1.88 & 4.88 & - & 2.92 & 27 \\
\hline 18 & - & - & 3.48 & - & 26.72 & 132.4 \\
\hline 19 & - & 1.5 & 9.8 & - & 6.3 & 24.2 \\
\hline 20 & - & 0.07 & - & - & - & 88.9 \\
\hline 21 & 0.0001 & 0.0001 & - & 0.0002 & 0.0001 & - \\
\hline 22 & 4.18 & - & - & - & - & - \\
\hline 23 & - & 0.0003 & 0.001 & - & 0.002 & 0.005 \\
\hline $24 a$ & - & - & - & - & - & 0.002 \\
\hline $24 \mathrm{~b}$ & - & - & - & - & - & 0.002 \\
\hline 25 & - & 0.02 & - & 0.34 & 0.2 & - \\
\hline 26 & - & 0.09 & 0.53 & - & 0.92 & 39.6 \\
\hline $27 \mathrm{a}$ & - & 0.17 & 0.98 & - & 0.5 & 22 \\
\hline $27 \mathrm{a}$ & - & 0.3 & 3.4 & - & 1.0 & 18.4 \\
\hline 28 & - & 0.45 & 1.26 & - & 0.61 & 40.2 \\
\hline 29 & - & - & - & 0.4 & - & - \\
\hline $30 \mathrm{a}$ & - & - & 20.5 & - & - & 156.8 \\
\hline $30 \mathrm{~b}$ & - & - & 14.4 & - & - & 142.1 \\
\hline 31 & - & - & 0.001 & - & - & 0.006 \\
\hline 32 & - & 1.74 & 5.75 & - & 2.75 & 29.62 \\
\hline 33 & - & 0.6 & 50.0 & - & 3.0 & 220 \\
\hline 34 & - & 0.006 & 0.005 & - & 0.001 & 0.0001 \\
\hline $35 \mathrm{a}$ & - & - & 0.006 & - & 0.004 & - \\
\hline $35 \mathrm{~b}$ & - & - & 0.006 & - & 0.003 & - \\
\hline 36 & 0.23 & 0.35 & 2.14 & 70 & 0.68 & 86.2 \\
\hline 37 & - & 0.48 & 25.4 & - & 1.72 & 394.4 \\
\hline 38 & - & 0.31 & 1.3 & - & 2.62 & 10.78 \\
\hline 39 & - & 0.1 & 1.0 & - & 1.1 & - \\
\hline 40 & - & 0.17 & 1.06 & - & 1.63 & 21.77 \\
\hline 41 & - & - & - & 0.01 & - & - \\
\hline 42 & - & 0.0006 & 0.0005 & - & 0.0004 & 0.0003 \\
\hline $43 a$ & - & 0.55 & 1.73 & - & 10.75 & 8.25 \\
\hline $43 b$ & - & 1.74 & 5.75 & - & 2.75 & 29.62 \\
\hline 44 & - & 0.02 & 1.11 & - & 0.43 & 21.7 \\
\hline $45 \mathrm{a}$ & 0.004 & 0.0001 & 0.005 & 0.0001 & 0.0001 & 0.03 \\
\hline $45 b$ & 0.003 & 0.0001 & 0.006 & 0.0001 & 0.0001 & 0.02 \\
\hline $45 \mathrm{c}$ & 0.003 & 0.0001 & 0.005 & 0.0001 & 0.0001 & 0.02 \\
\hline $45 \mathrm{~d}$ & 0.003 & 0.0001 & 0.002 & 0.0001 & 0.0001 & 0.03 \\
\hline $45 \mathrm{e}$ & 0.002 & 0.0001 & 0.007 & 0.0001 & 0.0001 & 0.02 \\
\hline 46 & - & 0.0001 & 0.001 & 0.002 & 0.0001 & - \\
\hline 47 & 0.0001 & 0.0001 & 0.001 & 0.0001 & 0.0001 & 0.003 \\
\hline
\end{tabular}




\begin{tabular}{lllllll}
48 & 0.002 & 0.0001 & 0.005 & - & 0.0008 & 0.02 \\
49 & - & - & - & - & - & 41.07 \\
\hline Food Standard & $2.0 \#$ & 2.0 & 10.0 & 0.5 & 0.5 & 200 \\
\hline
\end{tabular}

(ND) not detected.

(\#) inorganic As.

$(-)$ no analysis.

\section{Conclusions and recommendations}

This review demonstrates a very widespread world-wide use of Mugil cephalus in biomonitoring studies in the coastal zone and considers the potential to develop upon this further for biomonitor studies with fish. These studies all have an underlying objective of determining fish health and potential exposure risk to humans consuming M. cephalus, which is particularly important given the high rates of consumption of this species. There were subtle differences in the methodology and data collected which highlights the challenge in achieving a completely balanced assessment and benchmarking exercise among studies. This review has demonstrated that $M$. cephalus in many study regions have low uptake of contaminants and at this stage, $M$. cephalus in many coastal locations comply with the Australian and New Zealand Food Safety Standard. The results, however, provide evidence that some coastal regions support fish that are unsafe to eat, a response presumably to uncontrolled and unregulated waste disposal in to coastal wetlands.

The wide geographical distribution of this fish species assists with benchmarking contaminant concentrations in local populations compared to populations elsewhere, but to achieve this requires comparable data which, on the basis of this review, could be done better. To achieve this for M. cephalus, the following recommendations are necessary in future studies:

1) Sample and laboratory methodology, and data must be clear with no ambiguity reported leading to confusion and criticism concerning quality of the data;

2) Laboratory and field quality assurance and quality control testing should be sufficient to improve confidence in the data presented and underlying study conclusions;

3) Assessment of morphological measurements, including fish condition and health assessment, and implication of skin in the assessment of edible fish muscle analysis;

4) Examination of water and sediment samples at sites to provide a clear understanding of the extent of contamination, and to assist with examination of uptake; and

5) Inclusion of gill and liver, along with muscle, tissue analysis to examine the underlying mechanisms of contaminant uptake and accumulation in fish species.

Examination of contaminant accumulation in marine organisms is becoming increasingly important in coastal monitoring programs in response to assessment of bioaccumulation of anthropogenic waste discharged and examination of the exposure risks to humans consuming seafood sourced from coastal waters (McKinley and 
Johnston, 2010; Gall et al., 2012). The development of comparable datasets is critical to the success of biomonitoring programs, so that meaningful comparisons can be made, particularly in response to restoration efforts implemented by managers. Our recommendations are important for future biomonitor studies involving M. cephalus, and extend to other coastal fish species more broadly.

\section{Acknowledgements}

Gold Coast City Council funded this review.

\section{References}

Afonso, C., Lourenc, H.M, Abreu Dias, M.L., Nunes, M.L., Castro, M., 2007. Contaminant metals in black scabbard fish (Aphanopus carbo) caught off Madeira and the Azores. Food Chem., 101, 120-135.

Allan, I.J., Vrana, B., Greenwood, R., Mills, G.A., Roig, B., Gonzalez, C., 2006. A "toolbox" for biological and chemical monitoring requirements for the European Union's Water Framework Directive. Talanta, 69, 302-322.

Alquezar, R., Markich, S. J., Booth, D. J., 2006. Metal accumulation in the smooth toadfish, Tetractenos glaber, in estuaries around Sydney, Australia. Environ. Poll. 142, 123-131.

Ambedkar, G., Muniyan, M., 2011. Accumulation of metals in the five commercially important freshwater fishes available in velar river, Tamil Nadu, India. Arch. Appl. Sci. Res. 3, 261-264.

ANZECC/ARMCANZ, 2000. Australian and New Zealand guidelines for freshwater and marine water quality. Volume 1 and Volume 2. Environment Australia, Canberra.

ANZFA, 1999. Australian and New Zealand Food Standards Code. Issue 47. Australian and New Zealand Food Authority, Canberra.

Al-Yousuf, M.H., El-Shahawi, M.S., Al-Ghais, S.M., 2000. Trace metals in liver, skin and muscle of Lethrinus lentjan fish species in relation to body length and sex. Sci. Total Environ. 256, 87-94.

Authman, M.M.N., Abbas, H.H.H., 2007. Accumulation and distribution of copper and zinc in both water and the same vital tissue of two fish species (Tilapia zilli and Mugil cephalus) of Lake Qarun, Fayoum province, Egypt. Pakistan J. Biol. Sci. 10, 2106-2122.

Bahnasawy, M., Khidr, A.A, Dheina, N., 2009. Seasonal variations of heavy metals concentrations in mullet, Mugil cephalus and Liza ramada (Mugilidae) from Lake Manzala, Egypt. J. App. Sci. Res. 5, 845-852.

Bebbington, G.N., Mackay, N.J., Chvojka, R., Williams, R.J., Dunn, A., Auty, E.H., 1977. Heavy metals, Selenium and Arsenic in nine species of Australian commercial fish. Aust. J. Mar. Freshwa. Res. 28, 277-286.

Bervoets, L., Blust, R., 2003. Metal concentrations in water, sediment and gudgeon (Gobio gobio) from a pollution gradient: relationship with fish condition factor. Environ. Poll. 126, 9-19. 
Bervoets, L., Voets, J., Covaci, A., Chu, S., Qadah, D., Smolders, R., Schepens, P., Blust, R., 2005. Use of transplanted zebra mussels (Dreissena polymorpha) to assess the bioavailability of microcontaminants in Flemish surface waters. Environ. Sci. Technol, 39, 1492-1505.

Boubonari, T., Kevrekidis, T., Malea, P., 2009. Metal (Fe, Zn, Cu, Pb and Cd) concentration patterns in components of a macrophyte-based coastal lagoon ecosystem. Hydrobiol. 635, 27-36.

Canli, M., Atli, G., 2003. The relationships between heavy metal (Cd, Cr, $\mathrm{Cu}, \mathrm{Fe}, \mathrm{Pb}$, $\mathrm{Zn}$ ) levels and the size of six Mediterranean fish species. Environ. Poll. 121, 129-136.

Chen, M.H., 2002. Baseline metal concentrations in sediments and fish, and the determination of bioindicators in the subtropical Chi-ku Lagoon, SW Taiwan. Mar. Poll. Bull. 44, 703-714.

Chen, Y.C., Chen, C.Y., Hwang, H.J., Chang, W.B., Yeh, W.J., Chen, M.H., 2004. Comparison of the metal concentrations in muscle and liver tissue of fishes from the Erren River, southwestern Taiwan, after the restoration in 2000. J. Food Drug Anal. 12, 358-366.

Chen, H.Y., Teng, Y.G., Wang, J.S. 2012. A framework of characteristics identification and source apportionment of water pollution in a river: a case study in the Jinjiang River, China. Water Sci. Technol. 65, 2071-2078.

Chesapeake Bay Program, 2008. Chesapeake Bay 2007 Health and Restoration Assessment. Chesapeake Bay Program, Maryland.

Chouba, L., Kraiem, M., Mjimi, W., Tissaoui, C.H., Thompson, J.R., Flower, R.J., 2007. Seasonal variation of heavy metals $(\mathrm{Cd}, \mathrm{Pb}$, and $\mathrm{Hg})$ in sediments and in mullet, Mugil cephalus (Mugilidae), from the Ghar El Melh Lagoon (Tunisia). Transit. Waters Bull. 4, 45-52.

Cogun, H.Y., Yuzereroglu, T.A., Firat, O., Gok, G., Kargin, F. 2006. Metal concentrations in fish species from the northeast Mediterranean sea. Environ. Monit. Assess. 121, 431-438.

Colombo, J.C., Bilos, C., Lenicov, M.R., Colautti, D., Landoni, P., Brochu, C. 2000. Detritivorous fish contamination in the Rio de la Plata estuary: a critcal accumulation pathway in the cycle of anthropogenic compounds. Can. J. Fish. Aquat. Sci. 57, 1139-1150.

Dallinger, R., Prosi, F., Segner, H., Back, H., 1987. Contaminated food and uptake of heavy metals by fish: a review and proposal for further research. Oecologia 73, 91-98.

Djedjibegovic, J., Larssen, T., Skrbo, A., Marjanovic, A., Sober, M., 2012. Contents of cadmium, copper, mercury and lead in fish from the Neretva river (Bosnia and Herzegovina) determined by inductively coupled plasma mass spectrometry (ICP-MS). Food Chem. 131, 469-476.

Dunn, R.J.K., Teasdale, P.R., Warnken, J., Jordan, M., Arthur, J.M. 2007. Evaluation of the in situ, time-integrated DGT technique by monitoring changes in heavy metal concentrations in estuarine waters. Environ. Poll. 148, 213-220. 
Dural, M., Goksu, M., Ozak, A.A., 2007. Investigation of heavy metal levels in economically important fish species captured from the Tuzla lagoon. Food Chem. 102, 415-421.

Dural, M., Goksu, M., Ozak, A.A., Derici, B., 2006. Bioaccumulation of some heavy metals in different tissues of Dicentrarchus labrax L, 1758, Sparus aurata L, 1758 and Mugil cephalus L, 1758 from the Camil Lagoon of the eastern coast of Mediterranean (Turkey). Environ. Monit. Assess. 118, 65-74.

Edmonds, J.S, Francesconi, K.A., 1993. Arsenic in seafoods: human health aspects and regulations. Mar. Pollut. Bull. 26, 665-674.

Eustace, I.J., 1974. Zinc, cadmium, copper and manganese in species of finfish and shellfish caught in the Derwent Estuary, Tasmania. Aust. J. Mar. Freshwa. Res. 25, 209-220.

Fang, J., Wang, K.X., Tang, J.L., Wang, W.M., Ren, S.J., Wu, H.Y., Wang, J., 2004. Copper, lead, zinc, cadmium, mercury and arsenic in marine products of commerce from Zhejiang Coastal area, China, May 1998. Bull. Environ. Contam. Toxicol. 73, 583-590.

Frias-Espericueta, M.G., Osuna-Lopez, J.I., Jimenez-Vega, M.A., Castillo-Bueso, D., Muy-Rangel, M.D., Rubio-Carrasco, W., Lopez-Lopez, G., Izaguirre-Fierro, G., Voltolina, D., 2011. Cadmium, copper, lead and zinc in Mugil cephalus from seven coastal lagoons on NW Mexico. Environ. Monit. Assess. 182, 133-139.

Frias-Espericueta, Quintero-Alvarez, J.M., Osuna-Lopez, J.I, Sanchez-Gaxiola, C.M., Lopez-Lopez, G., Izaguirre-Fierro, G., Voltolina, D., 2010. Metal contents of four commercial fish species of NW Mexico. Bull. Environ. Contam. Toxicol. 85, 334-338.

Gall, M.L, Poore, A.G.B., Johnston, E.L., 2012. A biomonitor as a measure of an ecologically-significant fraction of metals in an industrialized harbour. J. Environ. Monit. 14, 830-838.

Hamza-Chaffai, A., Romeo, M., Abed, A.E., 1996. Heavy metals in different fishes from the middle eastern coast of Tunisia. Bull. Environ. Contam. Toxicol. 56, 766-773.

Huang, S.W., Chen, C.Y., Chen, M.H., 2008. Total and organic Hg in fish from the reservoir of a Chlor-alkali Plant in Tainan, Taiwan. J. Food Drug Anal. 16, 7580.

Has-Schon, E., Bogut, I., Strelec, I., 2006. Heavy metal profile in five fish species included in human diet, domiciled in the end flow of river Neretva (Croatia). Arch. Environ. Contam. Toxicol. 50, 545-551.

Heath, A.G., 1995. Water Pollution and Fish Physiology. CRC Press, Boca Raton, FL. Jordan, M.A., Teasdale, P.R., Dunn P.J.K., Lee, S.Y., 2008. Modelling copper uptake by Saccostrea glomerata with diffusive gradients in a thin film measurements. Environ. Chem. 5, 274-280.

Jones, J.C., Reynold, J. D., 1997. Effects of pollution on reproductive behaviour of fishes. Rev. Fish. Biol. Fisher. 7, 463-491.

Kalay, M., Ay, O., Canli, M., 1999. Heavy metal concentrations in fish tissues from the northeast Mediterranean Sea. Bull. Environ. Contam. Toxicol. 63, 673-681. 
Karadede, H., Unlu, E., 2000. Concentrations of some heavy metals in water, sediment and fish species from the Ataturk Dam Lake (Euphrates), Turkey. Chemosphere 41, 1371-1376.

Karouna-Renier, N.K., Snyder, R.A., Lange, T., Gibson, S., Allison, J.G., Wagner, M.E., Rao, K.R., 2011. Largemouth bass (Micopterus salmoides) and striped mullet (Mugil cephalus) as vectors of contaminants to human consumers in northwest Florida. Mar. Environ. Res. 72, 96-104.

Kennish, M.J., 2002. Environmental threats and environmental future of estuaries. Environ. Conserv. 29, 78-107.

Khaled, A., 2004. Heavy metals concentrations in certain tissues of five commercially important fishes from El-Mex Bay, Alexandria, Egypt. Egypt. J. Aquat. Biol. Fish. 8, 51-64.

Khoshnood, Z., Khoshnood, R., Mokhlesi, A., Ehsanpour, M., Afkhami, M., Khazaali, A., 2012. Determination of $\mathrm{Cd}, \mathrm{Pb}, \mathrm{Hg}, \mathrm{Cu}, \mathrm{Fe}, \mathrm{Mn}, \mathrm{Al}, \mathrm{As}, \mathrm{Ni}$ and $\mathrm{Zn}$ in important commercial fish species in northern of Persian Gulf. J. Cell Anim. Biol. 6, 1-9.

Kirby. J., Maher. M., Krikowa, F., 2001. Selenium, cadmium, copper and zinc concentrations in sediments and mullet (Mugil cephalus) from the southern basin of Lake Macquarie, NSW, Australia. Arch. Environ. Contam. Toxicol. 40, 246-256.

Kraal, M.H., Kraak, M.H.S., DeGroot, C.J., Davids, C., 1995. Uptake and tissue distribution of dietary and aqueous cadmium by Carp (Cyprinus carpio) Ecotoxicol. Environ. Saf. 31, 179-183.

Lee, S.Y., Dunn, R.J.K., Young, R.A., Connolly, R.M., Dale, P.E.R., Dehayr, R., Lemckert, C.J., McKinnon, S., Powell, B., Teasdale, P.R., Welsh, D.T., 2006. Impact of urbanisation on coastal wetland structure and function. Aust. Ecol. 31, 149-163.

Lewis, R.W., 1970. Fish cutaneous mucus: a review source of skin surface lipids. Lipids 5, 947-949.

Luoma, S. N., Rainbow, P. S., 2008. Metal contamination in aquatic environments: science and lateral management. Cambridge University Press, UK.

Liu, C.W., Lin, K.H., Jan., C.S., 2006. Tissue accumulation of arsenic compounds in aquaculture and wild mullet (Mugil cephalus). Bull. Environ. Contam. Toxicol. 77, 36-42.

McKinley, A., Johnston, E.L., 2010. Impacts of contaminant sources on marine fish abundance and species richness: a review and meta-analysis of evidence from the field. Mar. Ecol. Prog. Ser. 420, 175-191.

Maher, W., Goessler, W., Kirby, J., Raber, G., 1999. Arsenic concentrations and speciation in the tissues and blood of sea mullet (Mugil cephalus) from Lake Macquarie NSW, Australia. Mar. Chem. 68, 169-182.

Marks, P.J., Plaskett, D., Potter, I.C., Bradley, J.S., 1980. Relationship between concentrations of heavy metals in muscle tissue and body weight of fish from the Swan-Avon estuary, Western Australia. Aust. J. Mar. Freshwa. Res. 31, 783-793. 
Medeiros, R.J., dos Santos, L.M.G., Freire, A.S., Santelli, R.E., Braga, A.M.C.B., Krauss, T.M., Jacob, S.C., 2012. Determination of inorganic trace elements in edible marine fish from Rio de Janeiro State, Brazil. Food Cont. 23, 535-541.

Mohan, M., Deepa, M., Ramasamy, E.V., Thomas, A.P., 2012. Accumulation of mercury and other heavy metals in edible fishes of Cochin backwaters, Southwest India. Environ. Monit. Assess. 184, 4233-4245.

Mohammad, A., May, T., Echols, K., Walther, M., Manoo, A., Maraj, D., Agard, J., Orazio, C., 2012. Metals in sediment and fish from Sea Lots and Point Lisas Harbors, Trinidad and Tobago. Mar. Poll. Bull. 64, 169-173.

Odum, W.E. 1970. Utilization of the direct grazing and plant detritus food chains by the striped mullet Mugil cephalus. In: Steele, J. J (Ed.), Marine Food Chains. University of California Press Berkeley, CA, pp. 222-240.

Padmini, E., Rani, M.U, Geetha, B.V., 2009. Studies on antioxidant status in Mugil cephalus in response to heavy metal pollution at Ennore estuary. Environ. Monit. Assess. 155, 215-225.

Pauly, D., Christensen, V., Guenette, S., Pitcher, T.J., Sumaila U.R., Walters, C.J., Watson, R., Zeller, D., 2002. Towards sustainability in world fisheries. Nature 418, 689-695.

Plaskett, D., Potter, I.C., 1979. Heavy metal concentrations in the muscle tissue of 12 species of Teleost from Cockburn Sound, Western Australia. Aust. J. Mar. Freshwa. Res. 30, 607-616.

Prasath, P.M.D., Khan, T.H., 2008. Impact of tsunami on the heavy metal accumulation in water, sediments and fish at Poompuhar Coast, Southeast Coast of India. E-J. of Chem. 5, 16-22.

Priya, L.S., Senthilkumar, B., Hariharan, G., Selvam, A.P., Purvaja, R., Ramesh, R. 2011. Bioaccumulation of heavy metals in mullet (Mugil cephalus) and oyster (Crassostrea madrasensis) from Pulicat lake, south east coast of India. Toxicol. Indust. Health 27, 117-126.

Quinn, G.P., Keough, M., 2008. Experimental design and data analysis for biologists. Cambridge University Press, NY.

Reese, S.L., Estes, J.A., Jarman, W.M., 2012. Organochlorine contaminants in coastal marine ecosystems of southern Alaska: inferences from spatial patterns in blue mussels (Mytilus trossulus). Chemosphere 88, 873-880.

Ruelas-Inzunza, J., Paez-Osuna, F., Garcia-Flores, D., 2010. Essential (Cu) and nonessential $(\mathrm{Cd}$ and $\mathrm{Pb})$ metals in ichthyofaunas from the coasts of Sinaloa state (SE Gulf of California). Environ. Monit. Assess. 162, 251-263.

Ruelas-Inzunza, J., Paez-Osuna, F., 2007. Essential and toxic metals in nine fish species for human consumption from two coastal lagoons in the Eastern Gulf of California. J. Environ. Sci. Health, 42, 1411-1416.

Sacan, T.M, Altun, O., 2011. Heavy metal levels of five fish species inhabiting brackish water, the Kucukcekmece Lagoon, Istanbul (Turkey). Fresenius Environ. Bull. 20, 511-520.

Simpson, S., Batley, G.E., 2007. Predicting metal toxicity in sediments: A critique of current approaches. Integr. Environ. Assess. Manage. 3, 18-31. 
Sultana, R., Rao, D.P., 1998. Bioaccumulation patterns of zinc, copper, lead and cadmium in grey mullet Mugil cephalus (L.) from Harbour Waters of Visakhapatnam, India. Bull. Environ. Contam. Toxicol. 60, 949-955.

Tapia, J., Bertran, C., Araya, C., Astudillo, M.J., Vargas-Chacoff, L., Carrasco, G., Vaderrama, A., Letelier, L., 2009. Study of the copper, chromium and lead content in Mugil cephalus and Eleginops maclovinus obtained in the mouth of the Maule and Mataquito Rivers (Maule Region, Chile). J. Chil. Chem. Soc. 54, 36-39.

Turkmen, A., Turkmen, M., Tepe, Y., Mazlum, Y., Oymael, S., 2006. Metal concentrations in blue crab (Callinectes sapidus) and mullet (Mugil cephalus) in Iskenderun Bay, Northern East Mediterranean, Turkey. Bull. Environ. Contam. Toxicol. 77, 186-193.

Tuzen, M., 2009. Toxic and essential trace elemental contents in fish species from the Black Sea, Turkey. Food Chem. Toxicol. 47, 1785-1790.

Uluozlu, O.D, Tuzen, M., Mendil, D., Soylak, M., 2007. Trace metal content in nine species of fish from the Black and Aegean Seas, Turkey. Food Chem. 104, 835840.

Uysal, K., Emre, Y., Kose, E., 2008, The determination of heavy metal accumulation ratios in muscle, skin and gills of some migratory fish species by inductively coupled plasma-optical emission spectrometry (ICP-MS) in Beymelek Lagoon (Antalya/Turkey). Microchem. J. 90, 67-70.

Warne, M.St.J. 2001. Derivation of the Australian and New Zealand water quality guidelines for toxicants. Austral. J. Ecotox. 7, 123-136.

Waltham, N.J., Connolly, R.M., 2011. Global distribution and extent of artificial urban waterways. Estuar. Coast. Shelf Sci. 94, 192-197.

Waltham, N.J., Teasdale, P.R., Connolly, R.M. 2011. Contaminants in water, sediment and fish biomonitor species from natural and artificial estuarine habitats along the urbanized Gold Coast, Queensland. J. Environ. Monit. 13, 3409-3419.

Whitfield, A.K., Panfili, J., Durand, J.D. 2012. A global review of the cosmopolitan flathead mullet Mugil cephalus Linnaeus 1758 (Teleostei: Mugilidae), with emphasis on the biology, genetics, ecology and fisheries aspects of this apparent species complex. Rev. Fish Biol. Fisheries 22, 641-681.

Whitfield, A.K., Elliott, M., 2002. Fishes as indicators of environmental and ecological changes within estuaries: a review of progress and some suggestions for the future. J. Fish Biol. 61, 229-250.

Windom, H., Stickney, R., Smith, R., White, D., Taylor, F., 1973. Arsenic, cadmium, copper, mercury, and zinc in some species of North Atlantic finfish. J. Fish. Res. Board Can. 30, 275-279.

$\mathrm{Xu}$, Y., Wang, W. X., 2002. Exposure and potential food chain transfer factor of Cd, Se and $\mathrm{Zn}$ in marine fish Lutjanus argentimaculatus. Mar. Ecol. Prog. Ser. 238, 173-186. 
Yilmaz, A.B., 2003. Levels of heavy metals (Fe, $\mathrm{Cu}, \mathrm{Ni}, \mathrm{Cr}, \mathrm{Pb}$ and $\mathrm{Zn}$ ) in tissue of Mugil cephalus and Trachurus mediterraneus from Iskenderun Bay, Turkey. Environ. Res. 92, 277-281.

Yilmaz, A.B., 2005. Comparison of heavy metal levels of Grey Mullet (Mugil cephalus L.) and Sea Bream (Sparus aurata L.) caugh in Iskenderun Bay (Turkey). Turk. J. Vet. Anim. Sci. 29, 257-262.

Yilmaz, A.B., Dogan, M., 2008. Heavy metals in water and in tissues of himri (Carasobarbus luteus) from Orontes (Asi) River, Turkey. Environ. Monitor. Assess. 144, 437-444.

Yilmaz, A.B., 2009. The comparison of heavy metal concentrations ( $\mathrm{Cd}, \mathrm{Cu}, \mathrm{Mn}, \mathrm{Pb}$ and $\mathrm{Zn}$ ) in tissues of three economically important fish (Anguilla anguilla, Mugil cephalus and Oreochromis niloticus) inhabiting Koycegiz Lake-Mugla (Turkey). Turk. J. Sci. Tech. 4, 7-15. 